\title{
THE STUDY OF COLOR SCHEME OF MURAL PAINTING AND DECORATION IN INTERIOR ARCHITECTURE (CASE STUDY: TEMPLES IN KHONKAEN)
}

\author{
Nam-oi Saihoo \\ Architectural Department, Faculty of Architecture, King Mongkut's Institute of Technology Ladkrabang, \\ Bangkok, Thailand
}

Email:ksnam-oi @hotmail.com

\begin{abstract}
This research on the color scheme of Mural Paintings and Decorations in Interior Architecture. (Case Study: Temples in Khonkaen) This research shows the decorations and the color schemes in some important temples in Khonkaen which have significant mural paintings. The temples are Wat Sa Bua keo, Wat Sanuan Wari Phatthanaram, Wat Matchim Wittayaram.

The conclusions of the color scheme of Mural Paintings of 3 temples in Khonkaen are :Wat Sa Bua keo the color and style of the Mural Painting inside and outside are the same. Persumably they used the same painters working at the same time.The background is light color (cream color) and the story is painted in bright color. Wat Sanuan Wari Phatthanaram the color and style of the Mural Painting inside and outside are the same.The background is light color (cream color) and the story is painted in bright color, thus making the painting look airy. The painting inside is on the wall over the windows, because the temples is small and the windows are wide, so there is no space for painting between the windows like in the other temples. Wat Matchim Wittayaram, there are paintings inside and outside. The painting inside is only on the wall behind the Buddha image. There is no painting on the other wall. The color inside and outside are different, Perhaps the painters were different groups working at different times. The color outside has blue tone on the background instead of cream tone like in the other temples.

In this research, the researcher uses Pantone Color chart to match the colors at the site and uses YMCK mode to mix colors in computer. If the color is not exactly reproduced correct because of the printing process, interested persons can reproduce the colors by using the code given in this research to obtain the closest actual colors of this study.
\end{abstract}

Keywords: Sim, Mural Painting, Color Scheme

\section{Introduction}

This research focuses on the color scheme of E-sarn's mural paintings, both in the interior and exterior of the temples (a.k.a. Sim in Khonkaen) .The data is provided for students and interested persons for future practical application.

This research studies 3 temples which have significant mural paintings in northeastern part of Thailand in Khonkaen provinces.

\section{Objective of the research}

- To study and analyze the pattern of mural painting, focusing on the use of color schemes. 
- To conserve the data of color scheme for future practical application by using the color scheme in interior decoration or graphic works.

- The data will show the identity of the local northeastern province for the integrated usage.

\section{Research Methodology}

- Study by means of reviewing documental printing.

- Interview some well-informed persons in the local area and a scholar expert about the mural painting in the study.

- Take photos, and categorize the color by means of a computer software, PHOTOSHOP®.

- Analyze the relationship of color and pattern of the mural painting focusing on the use of color scheme of mural.

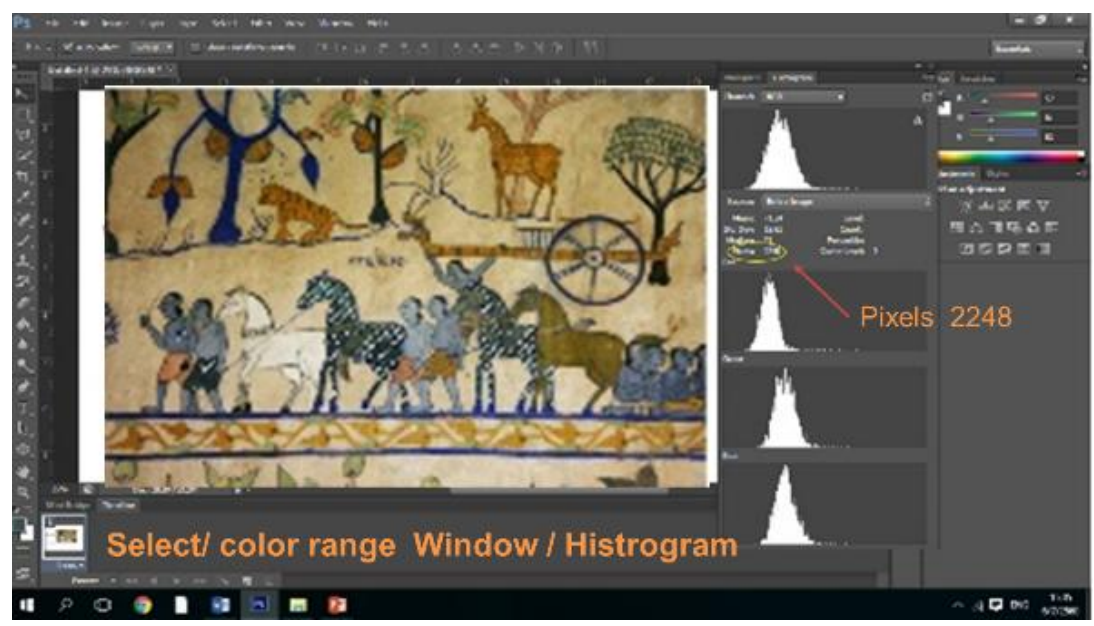

Figure 1: use computer software, PHOTOSHOP®.to categorize the color.

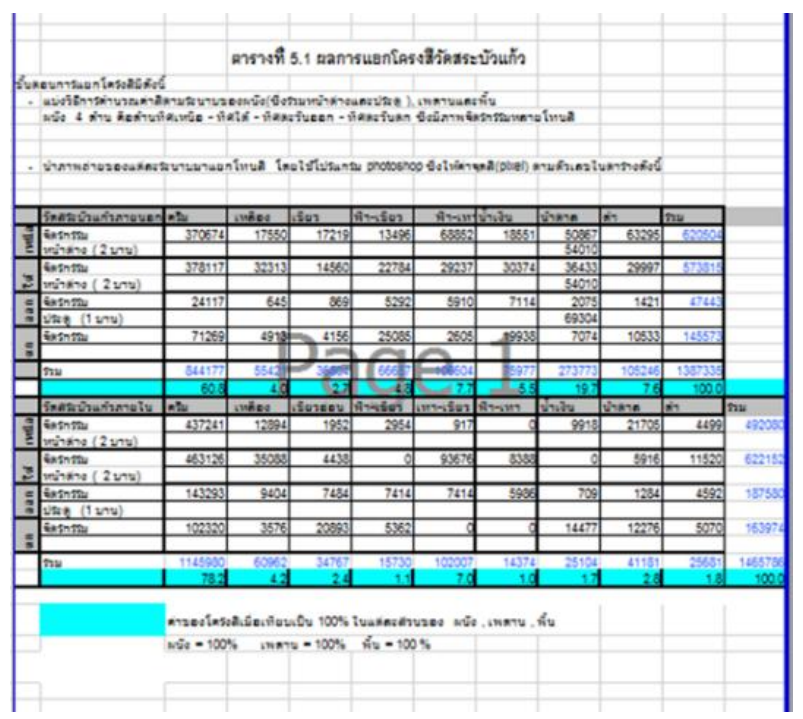

Figure 2: The percentage of color pixels from categorized data. 


\section{Case study}

This research chose 3 of the important temples in Khonkaen area which have significant mural paintings. The 3 temples (Sim) are

- Wat Sa Bua keo

- Wat Sanuan Wari Phatthanaram

- Wat Matchim Wittayaram

\section{Site Study:}

Khonkaenprovince in northeastern part of Thailand.

To the north and east of the region is bordered by Mekong river which run from the north, separates the region from Laos and Cambodia.In the west and south, is boarder by mountain range separates the region form the northern and central region of Thailand.

The northeast consist of 2 major parts, namely Korat Basin and Sakon Nakhon Basin.There are several major rivers such as Mun, Chi that flow into the Mekong river. 


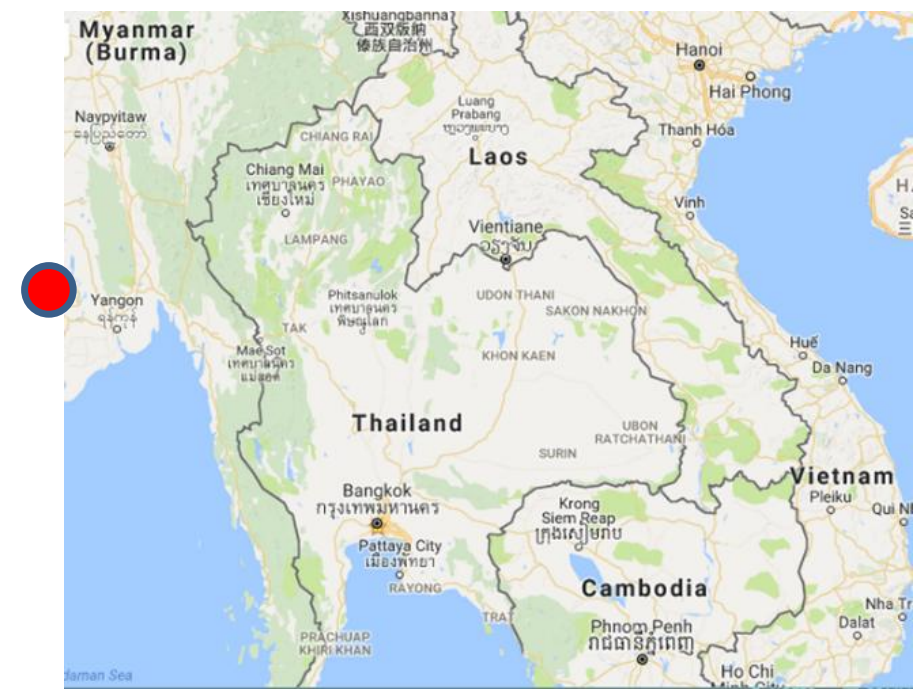

Figure 3: the location of Khonkean in northeastern part of Thailand

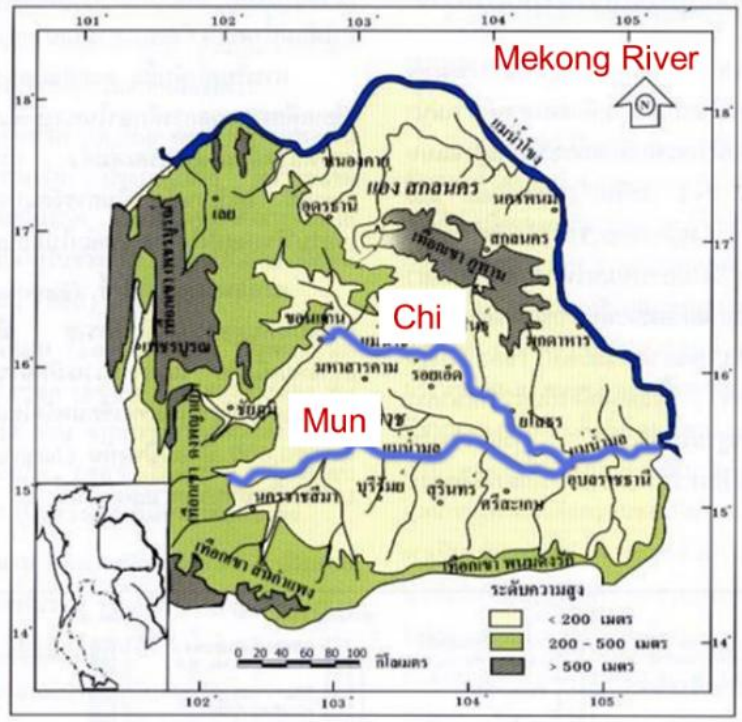

Figure 4: The Topography of the Region.

The majority of the people in the region belong to Thai- Lao linguistic group. They call themselves E-sarn Thai.

- The Mekong River communities: The majority were Laotian communities scattered along Mekong River.

- The Chi River communities: Suwannaphum were the center of the group, settle along the Chi River.

- The lower E-sarn communities:

The majority were Kui,Khmer and Korat Thai.They settle along the Mun river and the Kula Rong Hai Plain.

\section{Buddhism in northeastern region}

Ancient people believed in spirit and worshipped the Naga. After the spread of Buddhism, people not only has believed in Buddha but also still has worshipped the Naga. 

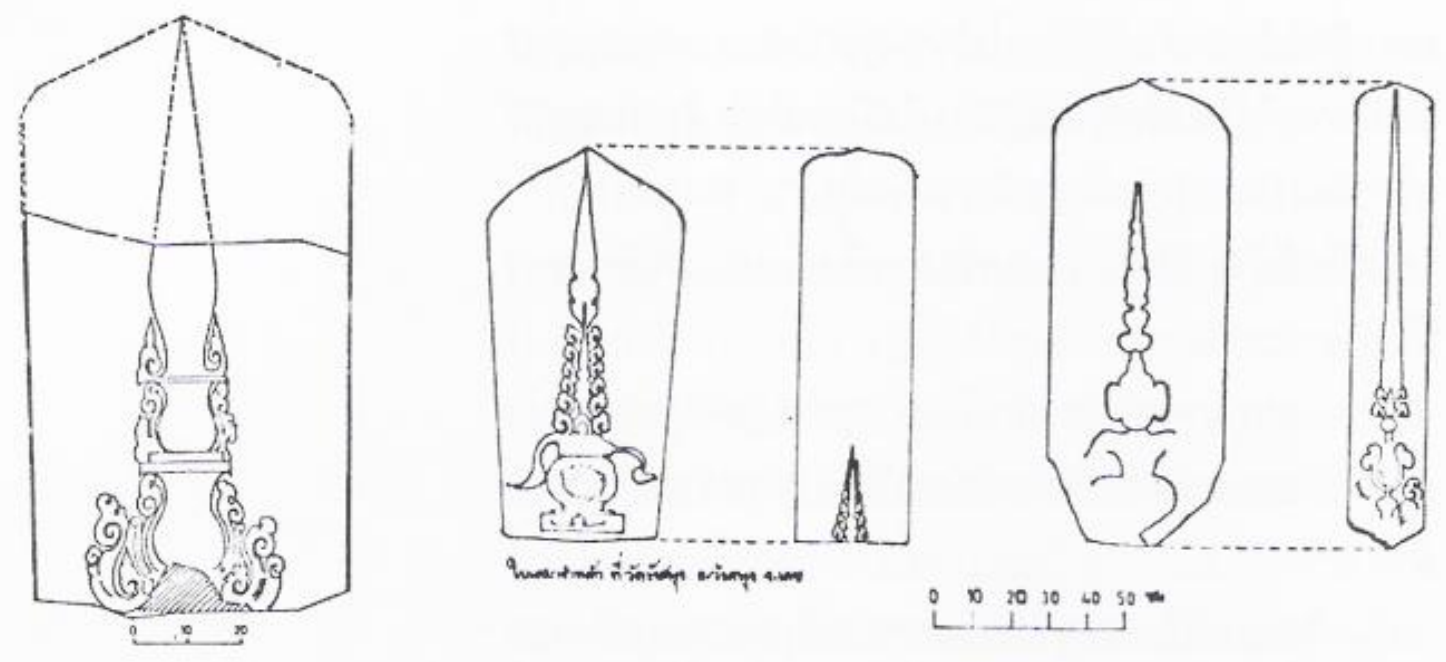

Figure 5: There are variety of ornamental motif carvings on boundary makers in northeastern region.

People used Sima for boundary makers to designate the religious territory in accordance with the Buddhist discipline. The word Sim derives from Sima or Sema meaning "Boundary marker"

Sim is defined as a holy place symbolizing goodness.

In the past, females were not allowed to enter the Sim area. Because of the small size of Sim, only the monks usually officiate any religious ceremony inside, except the common people will be seclude outside the Sim.

As the result, the public ceremony was done on a porch reaching out of the boundary area. 


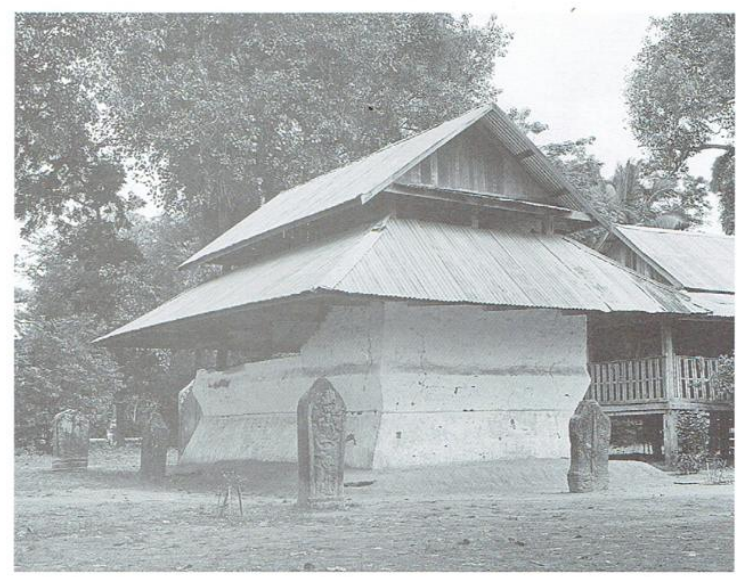

Figure 6: "Sim", the holy space with Sema, at Wat Bochaisemaram Karasin Province.

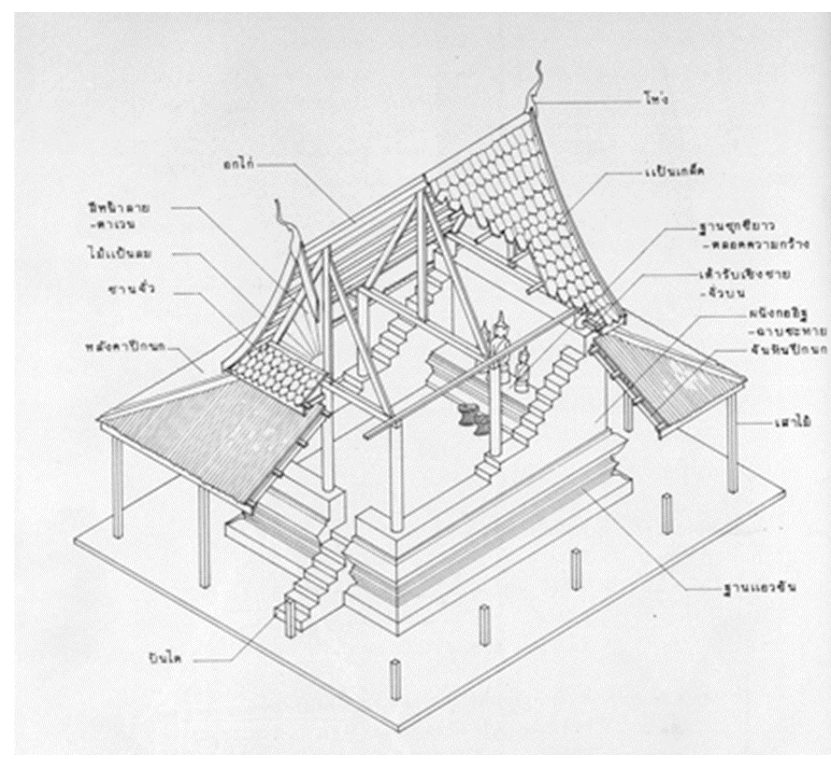

Figure 7: The structural elements of Sim.

\section{The Painting Cliff in Eastern Thailand}

- The painting has portrayed life ritual such as seasonal ceremony and death ceremony etc.

- Painting recorded the way of life such as hunting and farming.

- Mural painting shows various technics i.e.,

- Using body part such as palms, finger and dipped into color and paint or press on the wall.

- Using brushes made of wood or fur.

- Using natural color such as red soil.

- The purpose of the painting is also for decoration and aesthetic. 


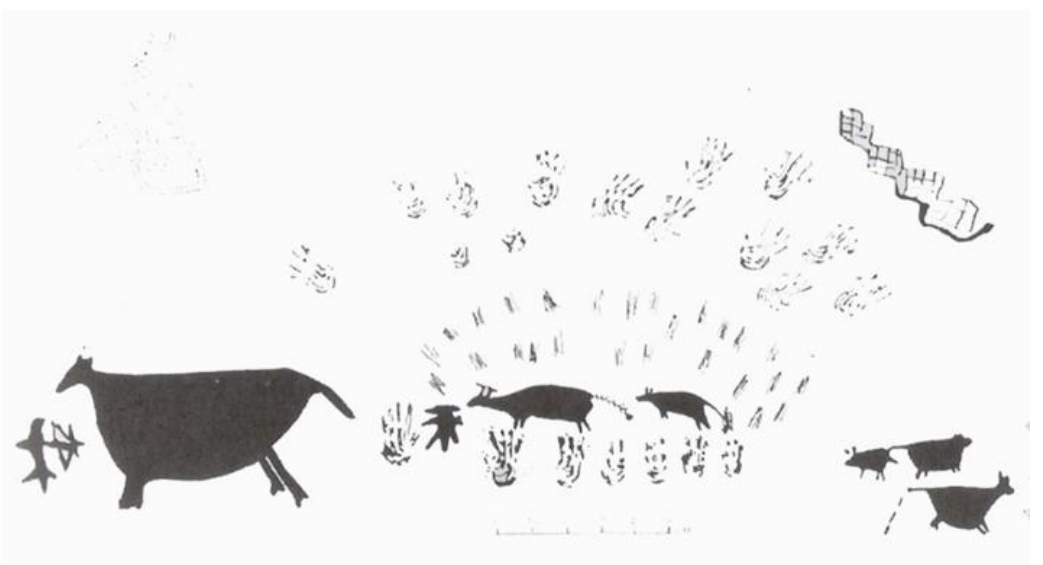

Figure 8: The Copy of the pre- historic painting in the cliff of Pha Mon Noi, Ubon ratchathani

\section{The Mural painting at Sim (tample)}

- The Mural painting not only portrayed the faith in religion but also aesthetic taste of the local people.

- The main theme of the Mural is about teaching and the story of Lord Buddha.

- The way of life and local story is also the content painted on the building walls, both inside and outside.

- The mural is painted on the wall of Sim.

- The color pigment are both natural and chemical substance.

- Wood or fur is used as brush.

The story of the mural painting

1. the Buddhist religious theme(the life of the Buddha) is inside walls.

2. "Sinsai", masterpiece of local literature, illustrating the right conduct of man as to moral teaching on outside walls.

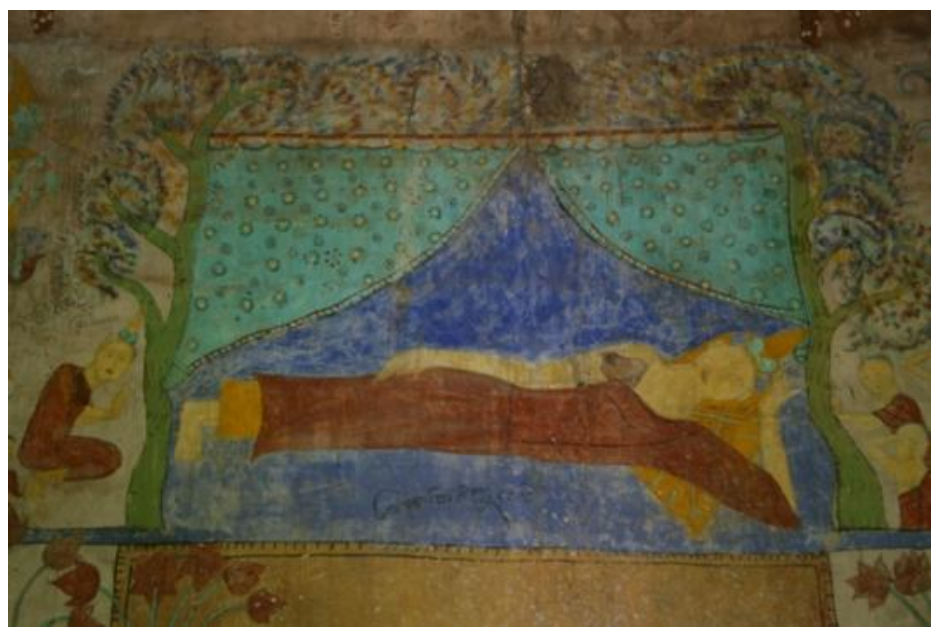

Figure 9: The mural painting inside is about the life of the Lord Buddha. 


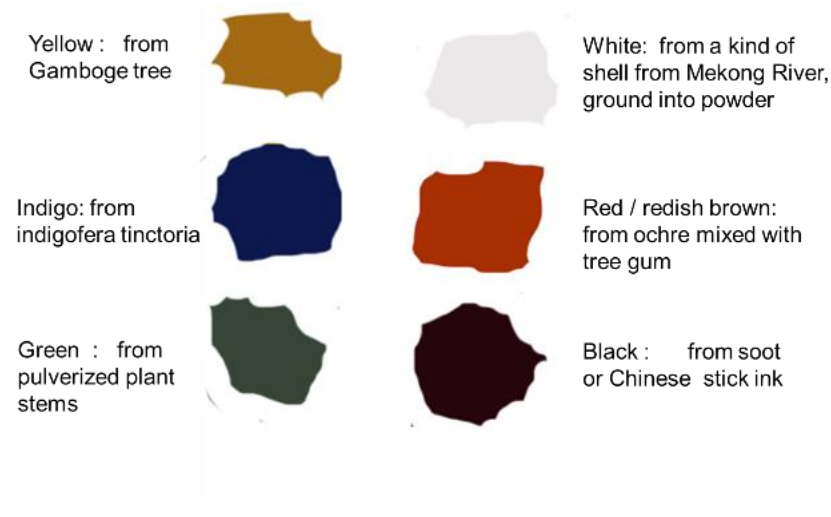

Figure 10: Natural colors that use in the mural painting.

\section{Painting Styles}

E- sarn painters are divide into 3 groups

1.Folk style group: works done by the local artisans.

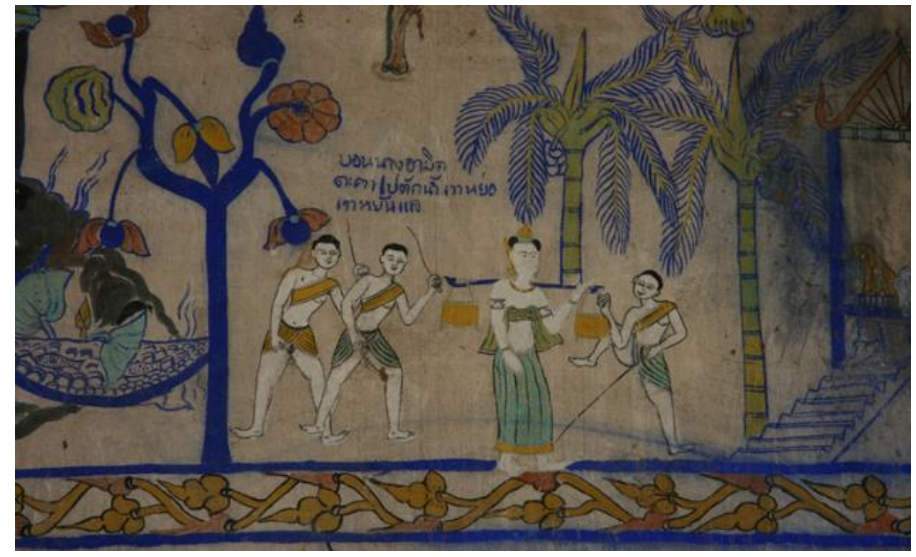

Figure 11: The interior painting (Vessantara Jataka) showed the way of life, especially the E-sarn costume

2.Royal court school group: works similar to traditional painting of the Royal Siamese Court school artists.

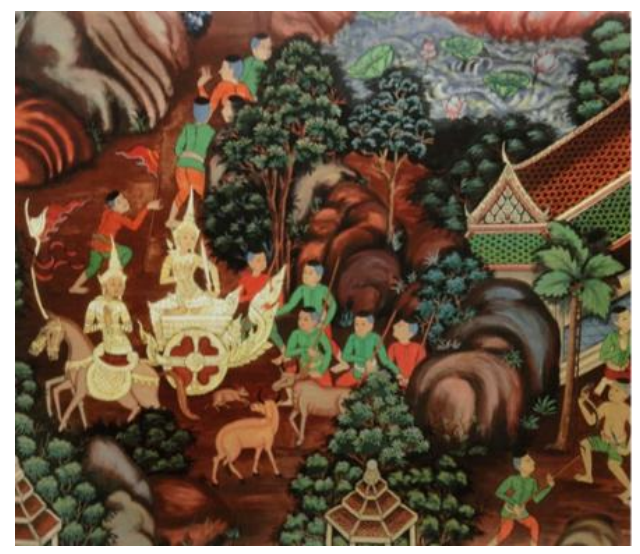

Figure 12: A mural painting scene from Wat Pho, Bangkok.

3. Lan Xang-Bangkok style group: works influenced by Lan Xang and the Royal Siamese Court school style. 

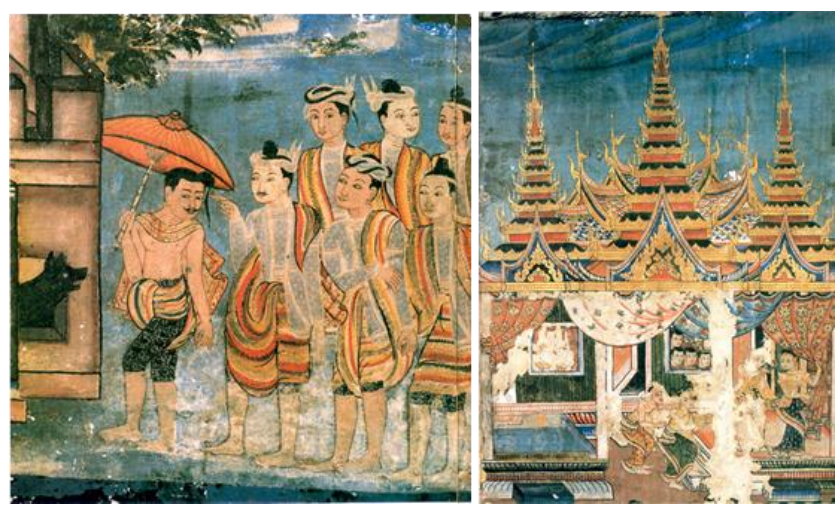

Figure 13:Mural painting scenes from a temple in Chiang Mai.

The painters are monks and villagers who have the relationship with their own village. The paintings are meant to be the oblation to Lord Buddha.

\section{Wat Sa Bua Keo}

4 Baanvangkun, Amphor Nongsonghong, Khonkean

The interior painting (Vessantara Jataka) showed the way of life, especially the E-sarn costume.

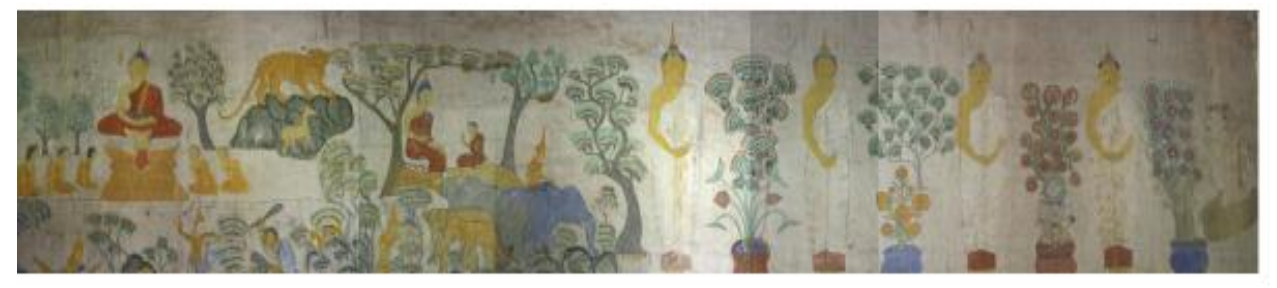

Figure 14: The Life of Lord Buddha mural painting in interior wall

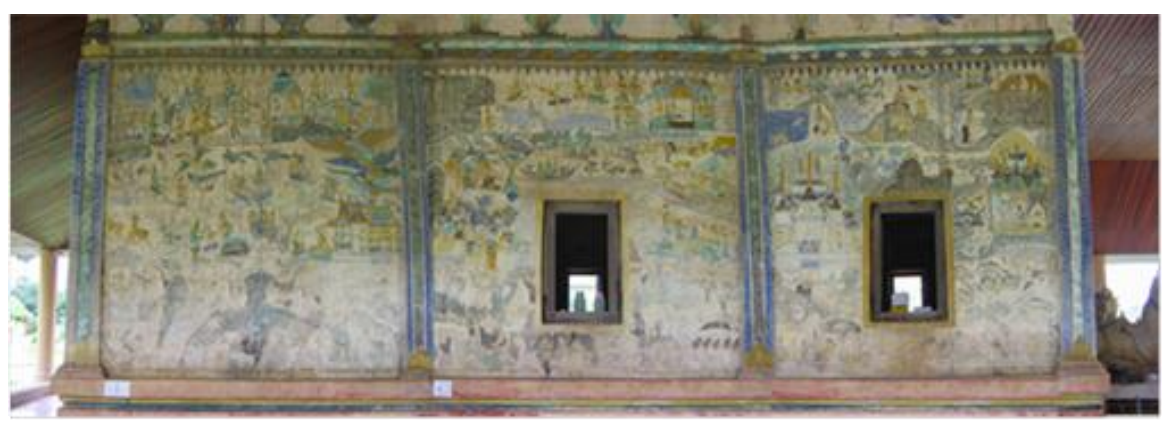

Figure 15: North elevation, The decoration of the exterior wall: the image of the local folk story. 


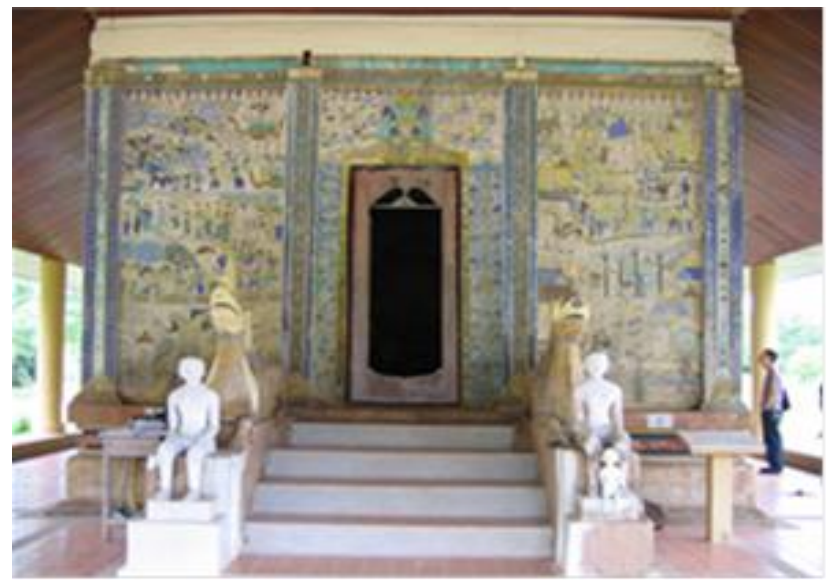

Figure 16: East elevation, main entrance of Sim.

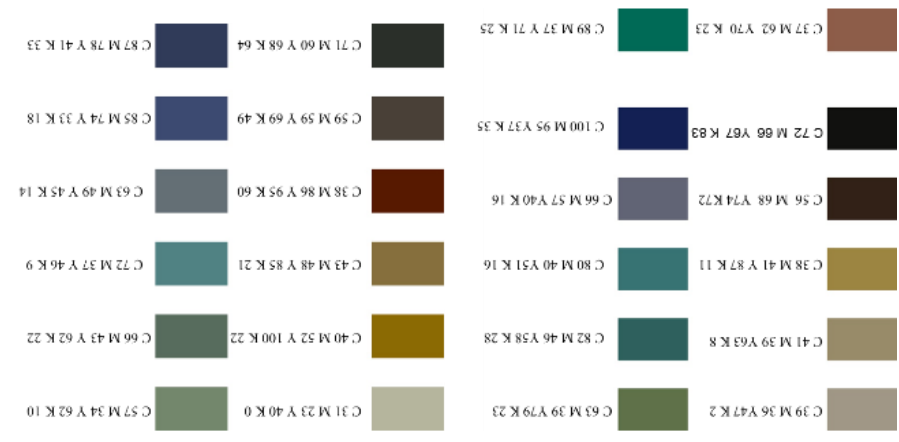

Figure 17: The color schemeof Wat Sa Bua Keo.

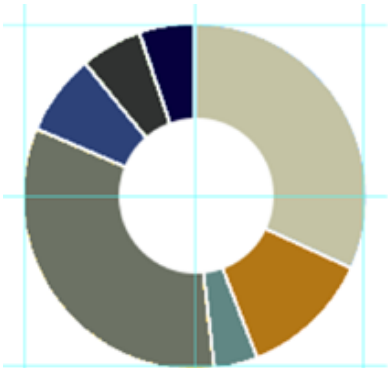

Exterior

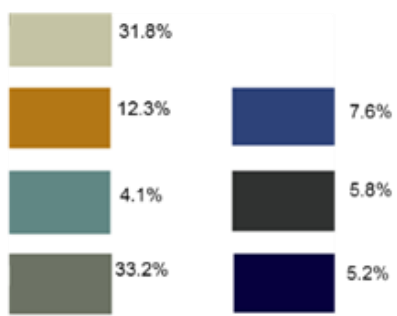

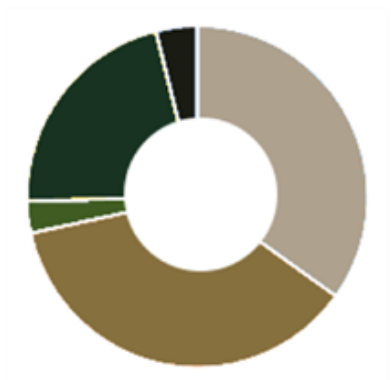

Interior

Figure 18: Percentage of the color scheme: Wat Sa Bua Keo 

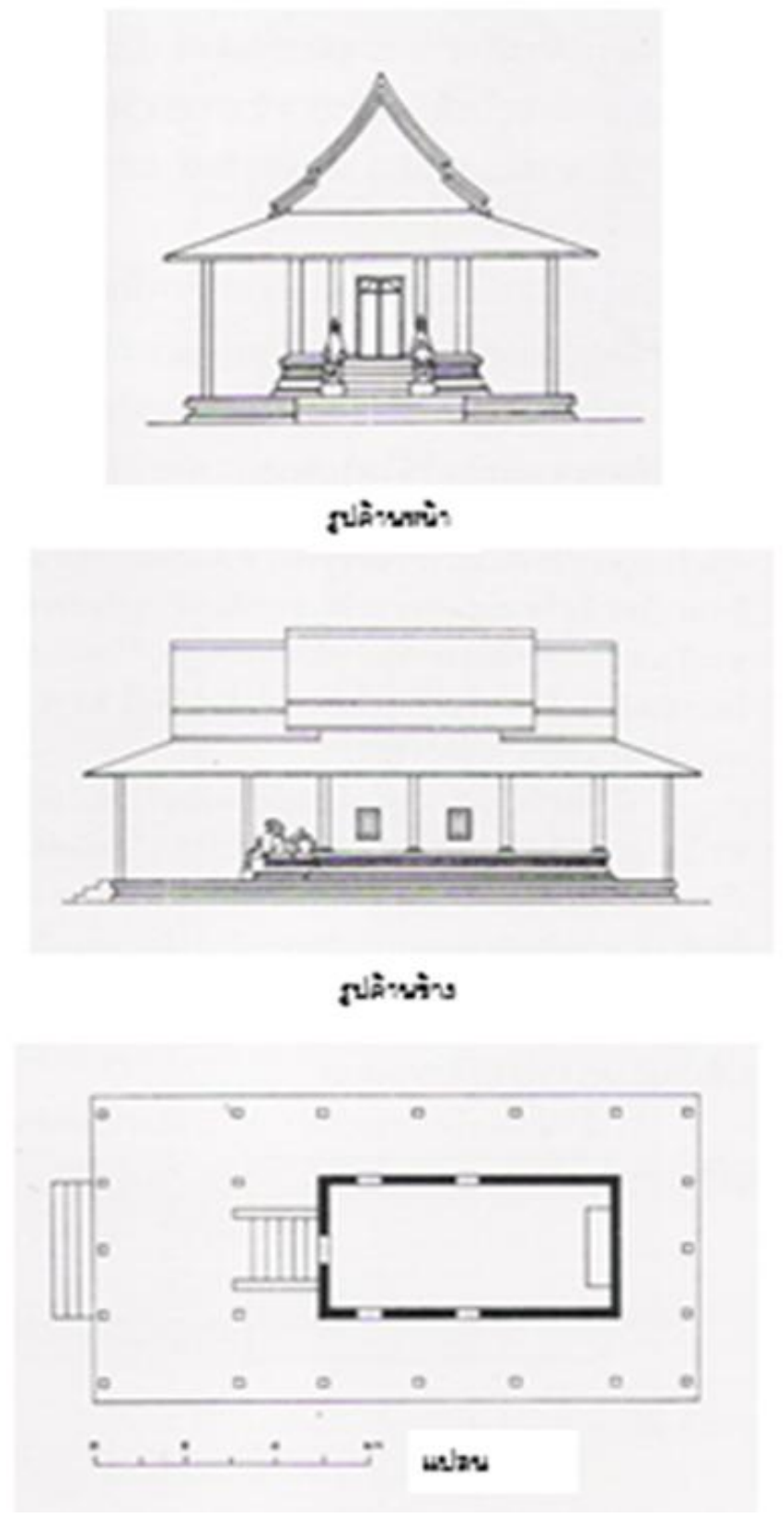

Figure 19: The architecture drawingof Wat Sa Bua Keo.

Wat Sanuan Wari Phatthanaram

Moo 1 BaannongBeau,Amphor Baanpai ,Khonkan 


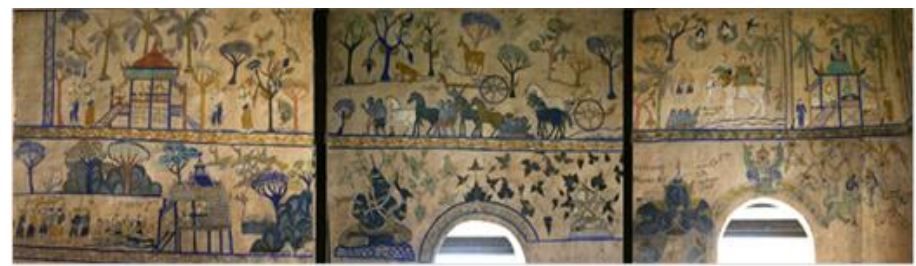

Figure 20: Interior Mural painging is the Buddhist religious theme, the past lives of the Lord Buddha: Vessantara Jataka

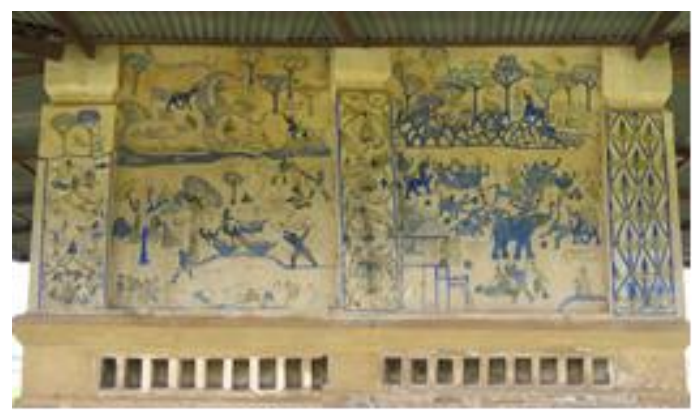

Figure21:the mural painting outside; The story of Sinsai, a local mythical hero.

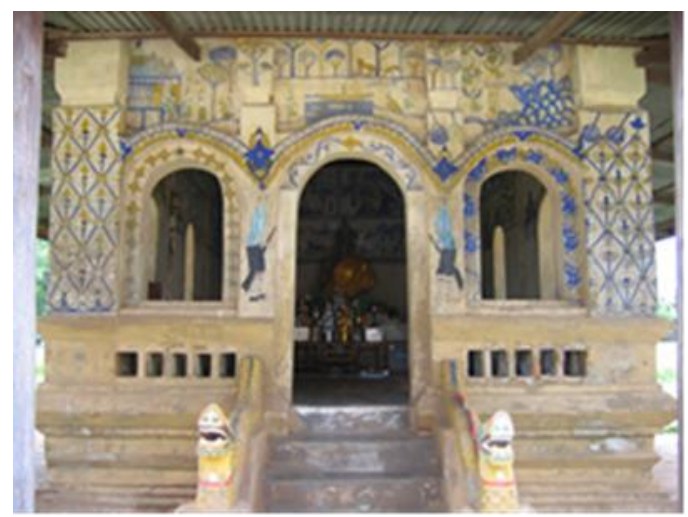

Figure 22: The door and windows are arch that have the Influenced by Western technic.

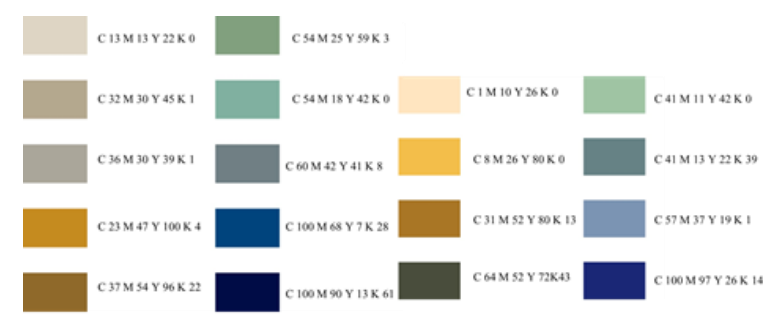

Figure 23:the color scheme ofWat Sanuan Wari Phatthanaram

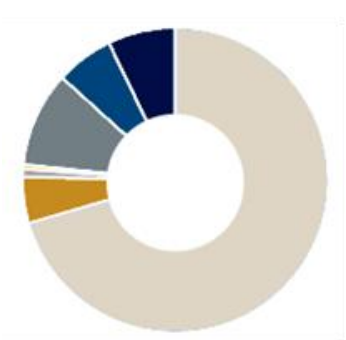

Exterior

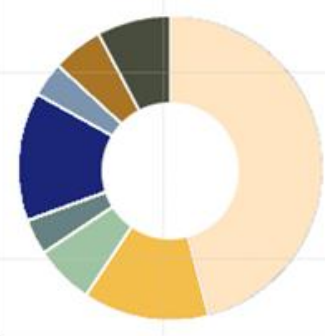

Interior 
Proceeding of the $4^{\text {th }}$ International Conference on Arts and Humanities, Vol. 4, 2017, pp. 18-33

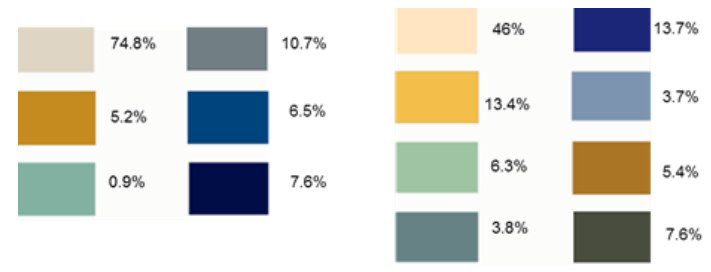

Figure 24: percentage of the color scheme: Wat Sanuan Wari Patthanaram
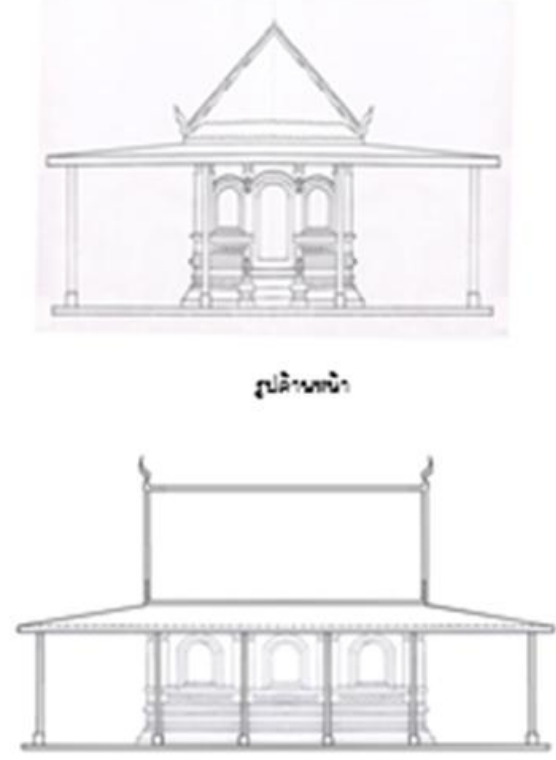

รปละพท่าง

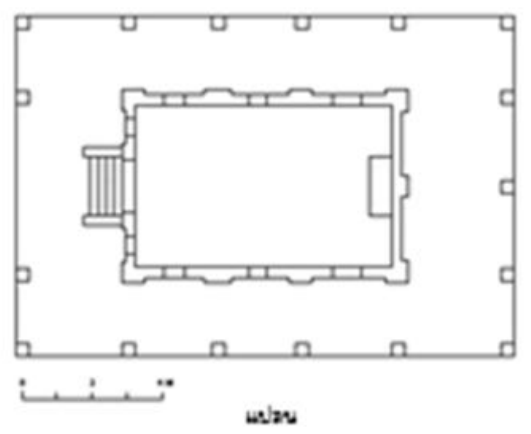

Figure 25: The architecture drawing of Wat Sanuan Wari Phatthanaram

Wat Matchim Wittayaram

Baan Lan,Amphor Baan Pai, Khonken 


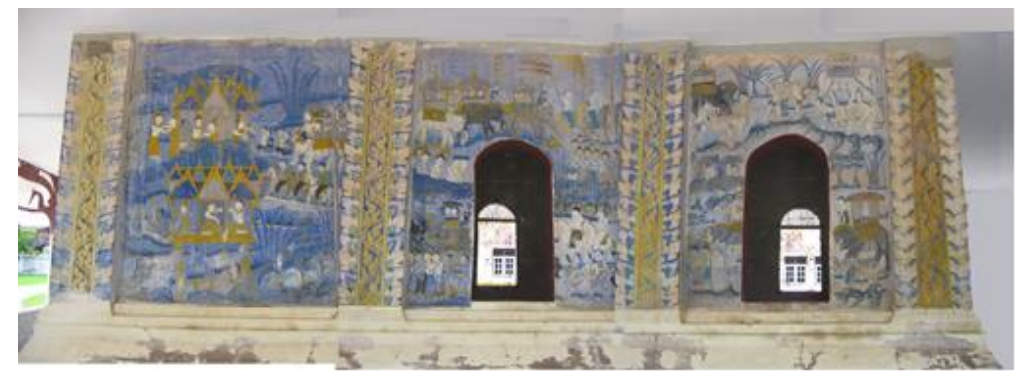

Figure 26: Detail of the exterior painting show the way of life of the people

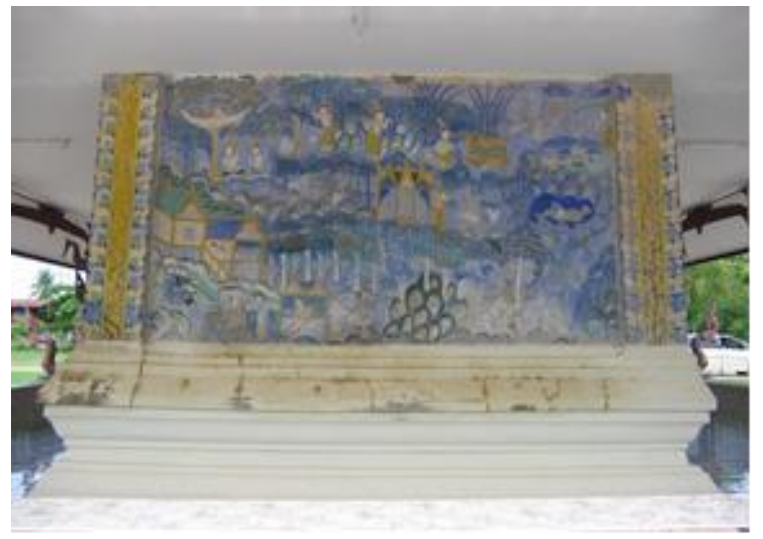

Figure 27:Vessantara Jatakas, this last past life of the Jatakas is imperative event to the E-sarn people

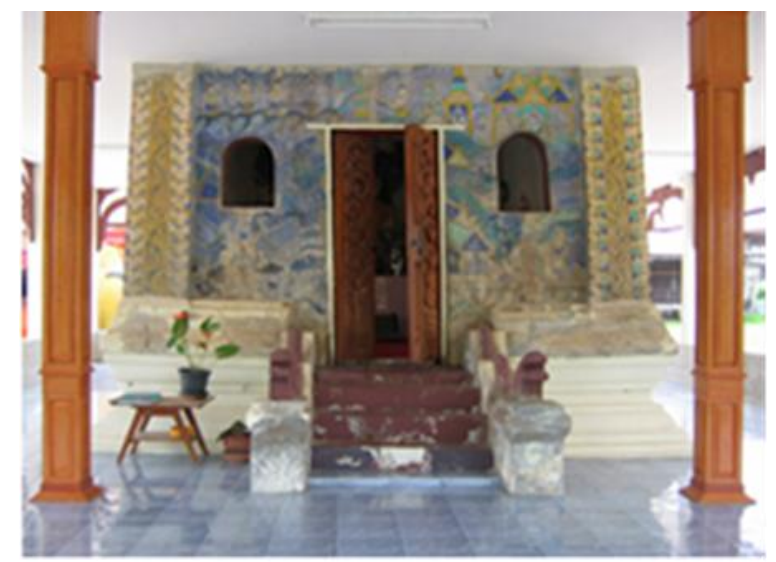

Figure 28: Two ornately Naga figure balustrades used on both sides of the staircase.

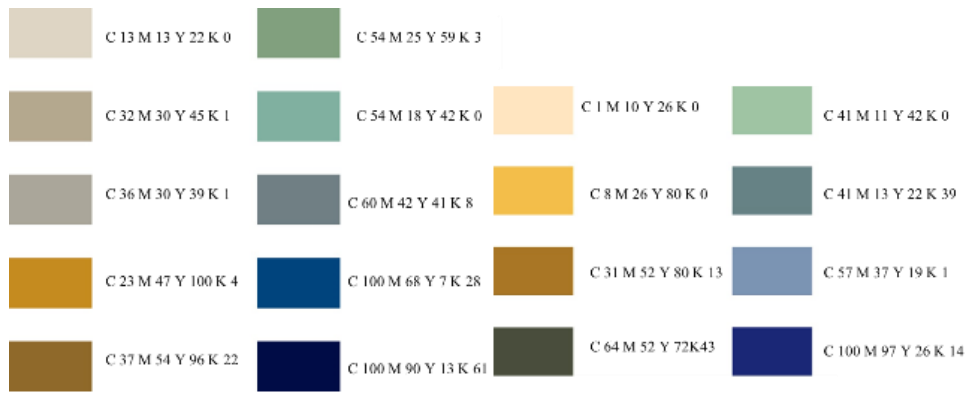

Figure 29: the color scheme of Wat Matchim Wittayaram 


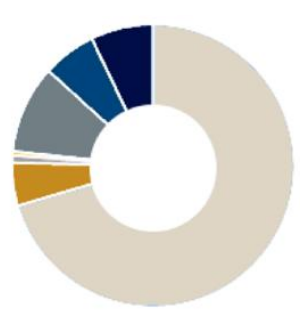

Exterior

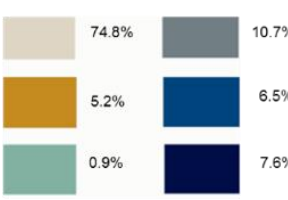

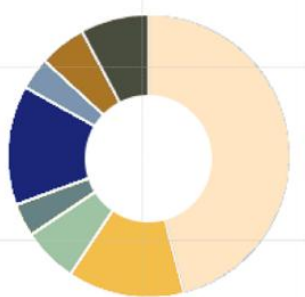

Interior

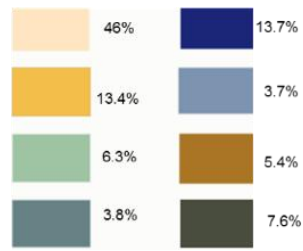

Figure30: Percentage of the color scheme:Wat Matchim Wittayaram

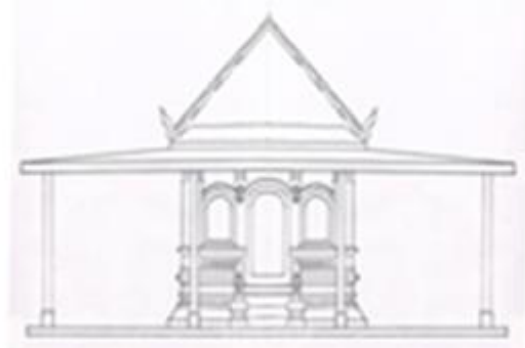

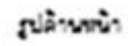

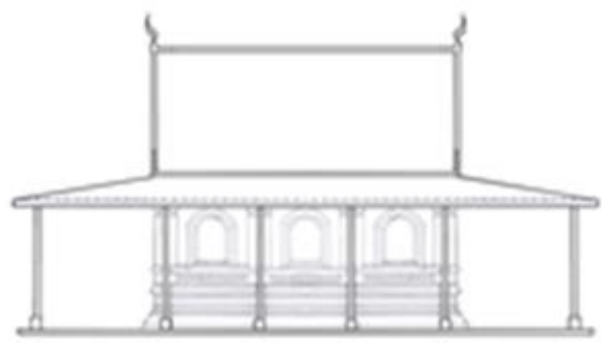

ส้ลัพท่าง

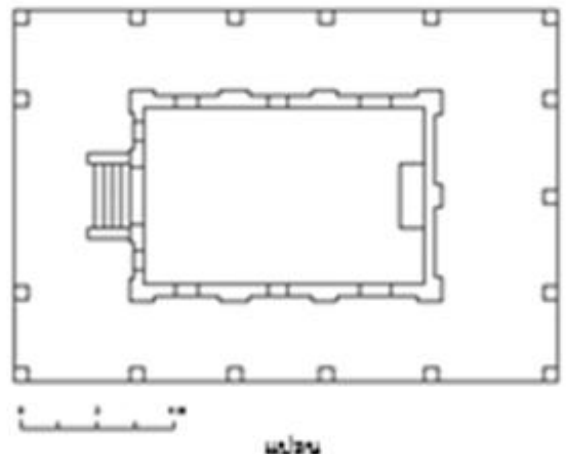

Figure 31: The architecture drawing of Wat Matchim Wittayaram 
Percentage of Color scheme of Mural Painting of 3 temples.

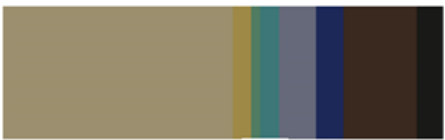

Exterior

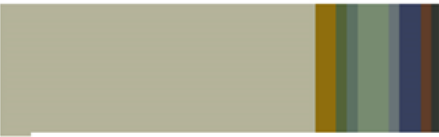

Interior

Wat Sa Bua keo

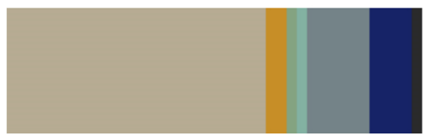

Exterior

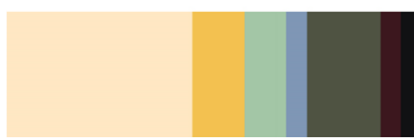

Interior

Wat Sanuan Wari Phatthanaram

Conclusion

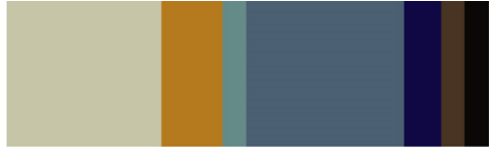

Exterior

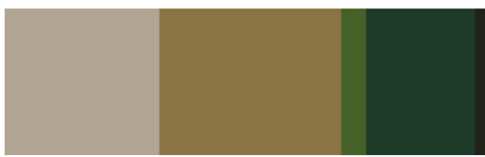

Interior

Wat Matchim Wittayaram

The mural painting of 3 temples have their own style of painting(Folk style). It seems that E-sarn mural artists were not strict in academic conventional order, they expressed their ideas in mural art unlike master artists works in the central Thailand who adhered to a strict order.

- The theme of the mural painting can be devided into

a. the Buddhist religious theme(the lives of the Buddha or Jataka.) on the interior walls.

b. masterpiece of local literature "Sinsai"(local mythical hero) to be depicted on exterior walls illustrating the human local virtue.

- The paintings portray the way of life of E-sarn people, i.e. built and natural environment.

- The background of the painting is tinted white due to the preparation of the wall with a wash of white of lime.

- The composition is unsophisticated.

- The color scheme is predominantly indigo blue and red ocher. In addition, a yellow represents of gold in some parts of the ornaments.

- The mural painting show the story to visual image for the people.

\section{Acknowledgements}

The author would like to express deep gratitude to King Mongkut's Institute of Technology Ladkrabang (KMITL), Thailand, for the financial support for my research. Sincere appreciation also goes to the Department of Architecture, KMITL, for the travel allowances to attend the 4th International Conference on Arts and Humanities 2017 (ICOAH 2017) in Colombo, Sri Lanka.

\section{References}

PAIROT SAMOSORN, 1989, E-sarn Murul Painting (Bangkok: Amarin Printing Group).

VIROT SRISURO, 1993, Sim E-sarn (Bangkok: Maka Press).

SISAK WANLIPHODOM ,2003, E-sarn Civilization, (Bangkok: Matichon Press).

SUMALEE EKCHONNIYOM, 2005, Mural Painting in Sim E-sarn Art of Mekong River, (Bangkok: Matichon Press).

UTONG PRASARTVINITCHAI, 2008, Hinden in Sim: Ko-Hor in E-sarn life. (Bangkok: Focal Image Printing Group). 